\section{Feelings and perceptions of women recovering from anorexia nervosa regarding their eating behavior}

\author{
Sentimentos e percepções de mulheres sobre \\ seu próprio comportamento alimentar durante \\ a recuperação da anorexia nervosa
}

\section{Sentimientos y percepciones de mujeres sobre su propio comportamiento alimentario durante la recuperación de la anorexia nerviosa}

Nathalia Petry

Francisco de Assis Guedes de Vasconcelos 1 Larissa da Cunha Feio Costa 1

\begin{abstract}
According to the phenomenological approach, observing a phenomenon through the perspective of those who lived it may be necessary to acquire fully comprehension of it. Therefore, to fully understand the eating behavior during anorexia nervosa and during its recovery, this study investigated individual perceptions and feelings of three women recovering from anorexia nervosa. This study is characterized as a qualitative research with phenomenological approach. The data were collected through interviews and analyzed following steps proposed by phenomenology researchers. During the anorexia nervosa experience, food restriction and irregular meal patterns were observed. Controlling food intake was associated with happiness. Guilt, anguish, sadness, fear and anger were associated with eating, and food was considered a villain. An obsessive thinking about food and a paradox between liking to eat and not wanting to eat were also observed. During recovery, it is important to have a more flexible eating behavior without negative feelings regarding food; however, feelings of guilty and fear were still detected. Perceptions about contact with nutritionists revealed the use of ineffective strategies. Although similarities were found in all reports, every woman had their own particular and singular experience. Rescuing their memories and experiences through their speech was important to fully understand and comprehend these personal experiences, and this complete understanding may enable health professionals to act more efficiently in the treatment of this complex phenomenon.
\end{abstract}

Anorexia Nervosa; Feeding and Eating Disorders; Eating Behavior; Emotions

\author{
Correspondence \\ N. Petry \\ Centro de Ciências da Saúde, Universidade Federal de Santa \\ Catarina. \\ Campus Universitário Reitor João David Ferreira Lima, \\ Florianópolis, SC 88040-900, Brasil. \\ nathaliaspetry@gmail.com \\ 1 Centro de Ciências da Saúde, Universidade Federal de Santa \\ Catarina, Florianópolis, Brasil.
}




\section{Introduction}

Anorexia nervosa is an eating disorder characterized by refusing to eat enough food to maintain a healthy body weight according to age and height; fear of weight gain or carrying excess weight; and the difficulty in recognizing the severe consequences of low body weight 1,2 . Morbidity and significant mortality are associated with anorexia nervosa 3 .

It is difficult to obtain an accurate estimation of individuals diagnosed with this condition for several reasons, including lack of training of health professionals; scarcity of records of diagnosed individuals; option of keeping the eating disorder secret by many individuals and use of different methodologies and locations by prevalence studies 4 . Thus, despite the world prevalence of anorexia nervosa among women was estimated at $4 \%$, the actual may be higher 3 .

The characteristic eating behavior in individuals with anorexia nervosa has been extensively described in the literature. Food restriction, irregular meal patterns, aversion to some macronutrients, prohibition of certain foods, fear of eating certain foods and food rituals are characteristic examples of eating behaviors in patients with anorexia nervosa 5,6,7,8. Binge eating episodes, characterized by eating a larger amount of food than normal within two hours with a feeling of loss of control, may also be present 1,2 . Studies have also shown the nutritional quality of these patients' intake and a common aversion to lipids associated to abnormal or higher intake of protein 6,9,10.

The eating pattern of anorexia nervosa during recovery has been identified. A greater flexibility when choosing foods and a diminished fear of eating have been observed 11,12 . However, since treating anorexia nervosa is a complex process, in which many beliefs about food, eating and body have to be changed, the maintenance of some characteristic eating behaviors in anorexia nervosa, such as prohibiting certain foods and food restriction, may persist during the recovery 13,14 .

However, according to the phenomenological approach each person would undergo an individual experience and would live the phenomenon in a singular manner. Thus, anorexia nervosa may be seen not only as a phenomenon per se, but it can also be observed through the perspective of the individual who is experiencing it 15,16,17. Therefore, according to phenomenology, understanding the individual's feelings and perceptions regarding the phenomenon may be important to fully understand it 16 .

Phenomenology is the study of phenomena. It explores the individual's experience and its meaning, describing it in its singularity as expressed by the individual. Thus, phenomenological research seeks to fully comprehend the experience from its primary data, disregarding theories, assumptions and judgments 15,16 .

When it comes to the field of psychopathology, the meaning of the experience is frequently multiple, and never reduced to a simple diagnostic. Instead of the common practice of traditional medicine of placing the patient within a specific diagnostic, the phenomenological approach allows a deeper comprehension of the psychopathologic living, understanding the biological, political, cultural, ideological meanings, without the perspective of theories and assumptions. The distinction between symptom and phenomenon is in the core of the phenomenological psychopathology and it represents a way of constructing and delimiting a phenomenological clinic model based on the experience. Research on phenomenological psychopathology allows a deeper comprehension of the individual's experience 18,19,20.

It was observed that most studies that analyzed eating behaviors during and after anorexia nervosa were mainly quantitative, which could adequately describe the eating behavior but usually do not explore the individual's perceptions or feelings associated with it 5,6,7,9,14. Thus, the qualitative research can be very important to fully understand the perspective of the individual, since it focuses on understanding the lived experience in all its senses and meanings, which cannot be adequately expressed in numbers 21 .

Thus, through qualitative research from the perspective of phenomenology, the objective of this study was to fully comprehend this guiding question: "How women in recovery of anorexia nervosa feel and think about their eating behavior both during and after this eating disorder experience?”. 


\section{Methods}

This study is a qualitative research 22 with a phenomenological approach $15,16,17,18,19,20$. The phenomenological method must seek the essence of the studied phenomenon, which can be achieved through three fundamental elements. The first element is the phenomenological reduction, which eliminates judgments and assumptions and allows the access to the individual's truth. The second element is the intersubjectivity, which refers to the relationship between the researcher and the researched: two histories interacting to understand the phenomenon. Lastly, the third element is the return to the lived experience, and the individual's return to his experience. These three elements were considered in this study 16 .

The methodological steps chosen were proposed by Amatuzzi 15: (1) delimit the object (phenomenon) to be studied and the guiding question; (2) meet the phenomenon, through the contact with those who experienced it; (3) analyze all information received, without judgments or assumptions, trying to capture and understand the essence; (4) go through all information, capturing the connections and meaningful aspects, in order to compose and establish the "units of meaning"; (5) the analyses proceed towards the articulation of these units, generating the results of the research; (6) these results allow a larger comprehension of the phenomenon, and it is possible to conclude the study; (7) the final step is to share the research with the scientific community.

After setting the guiding question, step two was accomplished through sample selection, which was conducted between January and May, 2013. The sample should be composed by women previously diagnosed with anorexia nervosa and currently recovering from this eating disorder. The inclusion criteria were: diagnosed with anorexia nervosa, female and participant of the multidisciplinary treatment of the Eating Disorder Ambulatory at the University Hospital of a public university in Brazil. In this ambulatory, the patients underwent individual psychological, nutritional and psychiatric treatment once a month and group psychotherapy once a week.

During the selection period, seven women participated the multidisciplinary treatment, and only three were diagnosed with anorexia nervosa. These women were selected for this research, and the ethical terms and privacy policy of this study were explained to them.

The chosen method to collect data was through interviews since it was seen as a good retrospective and phenomenological method to rescue the interviewee's memories 1 . The interviews were conducted using a semi-structured guide and the questions varied depending on the interview's course. The interviews were conducted in a place previously arranged with each interviewee and were recorded. Each woman was interviewed once, and the duration of the interviews was, on average, 1 hour and 10 minutes, ranging from 48 minutes to 1 hour and 30 minutes.

Each interview was analyzed individually and the key elements of each of them were selected for "units of meaning". For each interview, it was constructed a table with the units of meaning identified in the respective interview and the interviewee's reports related to each of these units. The collective analysis was carried out with a table containing the units of meaning selected in all interviews, the reports of the three interviewees related to each of these units and a concluding summary of each of these units. The table allowed the comprehension not only of the interviewees' individual experience, but also the understanding of these human experiences as a whole.

This research was approved by the Ethics Research Committee with Human Beings of Federal University of Santa Catarina, process 011421/2013, agreeing with the norms proposed by the Resolution 466/2012 of the National Council of Health.

\section{Results}

\section{Brief description of the interviewees}

The interviewees - codenames for this study Mel, Laura and Mary - were 21, 23 and 24 years old, respectively, at the time of the interviews. Mel and Laura were undergraduate students but they were not studying then, due to their eating disorder recovery process. Mary is graduated and works as a school teacher. 
Anorexia nervosa has started during adolescence in all three cases. Mel was 18 years old, Mary was 14 years old, and Laura could not recall this exact information. Laura and Mel started their treatment when they were approximately 20 years old, while Mary was 15 years old.

The interviewees reported a significant variation in their body weight during the anorexia nervosa experience. At the time of the interviews, when they were already in recovery, Laura, Mel and Mary presented a nutritional status classified as within the normal range 23, according to the body mass index (BMI) calculated for them, which were, respectively, 19.4, 22.7 and $23.4 \mathrm{~kg} / \mathrm{m}^{2}$.

In the core of the anorexia nervosa experience, Laura, Mel and Mary presented their lowest BMI, which was, respectively, $15.4,16.4$ and $16.8 \mathrm{~kg} / \mathrm{m}^{2}$, values that correspond to underweight 23 . The interviewees attributed their lowest BMI to the most critical phases of the disease, when food restriction and compensation methods predominated.

The highest BMI presented for them were, respectively, $22.2,25.5$ and $27.3 \mathrm{~kg} / \mathrm{m}^{2}$. It is not possible to conclude that Mel and Mary also reached a nutritional status classified as overweight 23. According to the three interviewees, weight gain occurred after starting their treatment, due to a reduction of compensatory methods, an increase in food intake, a greater flexibility when choosing foods, and a new mixed feeling between freedom regarding eating and a persistent guilt when eating, as observed in Laura's report:

"There were days that I felt like I was cured and even ate an entire chocolate bar. However, there were days that I thought I had eaten too much and thought: 'Now I have already ruined my day, I will eat everything"'.

\section{Feelings and perceptions regarding eating behavior during the anorexia nervosa experience}

Laura, Mel and Mary reported feelings of happiness when they were able to control their food intake, and restricting food was a goal in their lives at that time.

Laura commented she did not skip meals but tried to eat the least possible in each meal. Mel and Mary reported having as few meals as possible during the day and Mary also commented she would try to eat nothing during the day:

"I would try to eat nothing. Sometimes I would only have lunch during the entire day" (Mary).

Laura, Mel and Mary reported they could perceive and feel hunger but they used strategies to mask it. Tolerating and denying hunger were associated to a feeling of control and satisfaction:

"I used to deny it, but I could feel the hunger. And I remember there was always water near me, to mask the hunger" (Laura).

"I could feel it, and that was good, because it meant I had an empty stomach. I always had cereal bars with me too, to mask the hunger. Oh, one day I got myself intoxicated by chloroform on purpose, because it causes stomachaches, and having a stomachache, I was not able to eat. And not eating, I could lose weight" (Mel).

"I could feel it, I could feel an empty in my stomach, like a hole. Drinking water was good to mask this feeling” (Mary).

The interviewee has highlighted the parental presence during meals as a reason to eat. However, Laura reported some strategies she used not to eat in front of them, like a fake stomachache or just moving the food around the plate:

"I would try to eat nothing. But my mom would make me eat at least a little" (Mary).

"At night, I used to have dinner with my parents so I had to eat. However, sometimes my mom cooked unhealthy foods, like a lasagna, so I would skip the meal by pretending I had some stomachache or I would say I didn't like the food. Sometimes I could even put food on my plate and I was eating... moving the food around the plate..." (Laura).

When choosing what to eat, the interviewees commented they usually tried to choose the less caloric foods:

"In the morning, I would eat only half of a light cereal bar because it contains only about 72 or 80 calories" (Laura).

"At night I would try to cook some meat, without oil of course, and broccoli. I used to eat broccoli all the time, because it is healthy" (Mel).

Despite the fact they tried to choose the less caloric foods, it was also found that choosing their food preferences, the sweet and more caloric foods, was a common behavior in this study. Mel and Mary commented they would make self-negotiations, skipping meals in order to have something 
they preferred, as if this negotiation could alleviate the guilty of eating something more caloric and "unhealthier":

"I used to negotiate the lunch with myself, like 'If I skip lunch and wait until 3 o'clock, I will have a snack'. It's interesting how I preferred to skip lunch and wait for something unhealthy and delicious, instead of having a healthy meal for lunch" (Mel).

"Actually, the only thing I would still eat was chocolate. Two chocolate bars at afternoon" (Mary).

However, the interviewees reported feelings of fear when eating their preferred foods, sweets, because of their good flavor and their supposed potential of leading them to a binge-eating episode. Thus, the interviewees' food preferences became a love-hated object. It is also interesting to note that binge-eating episodes were moments when these foods were not only allowed but the first choices of the interviewees:

"I love chocolate but I feared it. Actually, chocolate, candy, cakes... I would be afraid of eating these foods unless it was a binge-eating episode" (Mary).

"I've always had the need of eating sweet things, but I feared them. Ice cream was the worst because it is so good but at the same time, it is so caloric and very easy to vomit. When I had binge-eating episodes, I would always choose ice cream" (Laura).

Laura, Mel and Mary reported feelings such as guilt, anger, anguish, sadness, fear and worry when eating because they used to see food as something that would make them fat. In fact, they attributed negative meanings to foods:

"I would describe the food as an evil thing in our society (...) When I finished eating, I felt horrible. Like as if I was cheating on myself. Like as if I was lying to myself. I felt guilty" (Laura).

"I used to see food as a villain. It's impossible to get rid of the guilt and the feelings associated with the food" (Mel).

"Food was a villain. I felt terrible after eating. I was so afraid... of getting fat" (Mary).

However, Laura, Mel and Mary also pointed out positive aspects of food, such as flavor. Laura and Mel commented they liked to eat and they constantly dreamed and thought about food. Thus, mixed feelings between liking/wanting to eat and hating/not wanting to eat were observed:

"Sometimes I liked to eat. I felt this strong desire of eating and sometimes I could even dream about it" (Laura).

"I got worried all the time about food. I couldn't eat but I also couldn't stop thinking about it!" (Mel).

\section{Perceptions and feelings about binge-eating episodes}

The binge-eating episodes were moments of giving up control, pleasure and freedom to eat whatever they want, mainly their preferred and feared foods. However, these episodes were followed by feelings of anger, sadness, shame, guilt and anguish. Laura also commented that she used to hide herself during these episodes because of guilt and shame. Laura and Mary reported they used compensatory methods, such as purgation, use of laxatives and self-mutilation after binge-eating episodes:

"I used to go to this bakery and order a piece of this pie, a piece of that pie, an ice cream, a soda, some snack, some candy... I would buy everything. Then I would go to a public bathroom to eat and throw up. God, I felt so bad I could kill myself. Sometimes, I would cut myself because of my anger" (Laura).

"I used to eat ice cream, snacks, soda and lots of candies. Or the biggest meal of McDonald's, with large fries, ice cream, dessert, Milk shake and popcorn. At first, you have this good feeling of having an urge satisfied. It's so pleasurable and feels so good! But after that, a feeling of guilt appears. You feel very, very guilty. I hated myself so much" (Mel).

"During the episode it was an unexplained pleasure. It was so good! I could eat whatever food I could find in front of me. Usually I looked for sweets. But after that I felt bad, so bad, so bad" (Mary).

The interviewees also reported that the binge-eating episodes would usually happen when they had eaten something they have not planned before, as an "all or nothing" thinking:

"Eating something I haven't previously planned to eat was like if I had ruined my day. So now I have ruined my day, I will eat more and throw up all this together" (Laura).

"If you're going to ruin your diet do it all at once" (Mel).

Now in recovery, Mel and Mary said the binge-eating episodes still persist in their lives, but they are less frequent and not followed by compensatory methods anymore: 
"Sometimes it happens, but it's less frequent. Before it could happen like twice a day" (Mel).

"It happens, but not frequent. Like every two weeks. But now I don't vomit" (Mary).

\section{Feelings and perceptions about eating behaviors after the anorexia nervosa experience}

Laura, Mel and Mary are currently in the recovery phase of anorexia nervosa. They commented changes in their eating behavior in comparison with their dietary habits during the anorexia nervosa experience. According to them, pursuing a diet with less rules and deprivation and having balanced food consumption became important. They still have sweet foods as their food preferences but they do not impose any restriction to them anymore and they try not to feel guilty or afraid when eating them. However, they would try not to eat them excessively because it could trigger a bingeeating episode:

"I try to have a colorful and nutritive meal. But when I can't have it I will not blame myself anymore. I can be flexible about what and when I eat. I don't restrict food anymore. I think I have had enough restriction in my life" (Mel).

"I try to follow a healthy and balanced life. But I still avoid ice cream because I don't want to have a bingeeating episode or even throw up" (Laura).

"I avoid having certain foods in my home, such as chocolate and condensed milk, because I'm afraid I would lose control" (Mary).

They also commented they could deal better with the perception of hunger now. Laura commented she still fears it a little bit though, so she prefers having an eating routine in order to not feel hungry:

"When I'm hungry, I feel like I should eat. I don't need to mask the hunger anymore" (Mary).

"When I'm hungry, I get a little afraid. So I rather not reach the point when I get hungry. I eat before it gets to this point" (Laura).

Guilt and fear are still present in the interviewees' lives, but they try to avoid it. They reported they do not want to be slaves of anorexia nervosa anymore. Mel and Mary reported their dream is to "eat like a normal person" and they believe they are doing a great job until now.

"I try not to feel guilty. That's the only thing I think: killing this feeling of guilt. My dream is not to be sedentary and eat like a normal person. I think I'm doing a good job until now" (Mel).

Laura commented she still has some negative thoughts about food and weight, and she reported she does not believe she would eat normally someday. According to her, "that is all she can have":

"I still feel a little bit like slave of anorexia nervosa because I still have these thoughts. It annoys me, but that is all I can have" (Laura).

They also comment that sometimes they miss the way they looked when they had anorexia nervosa, but they believe they are healthier now:

"Now I'm not restricting I'm not able to have the weight I would like to have" (Mel).

"There are some moments I look at my old pictures and miss my old appearance, but I think it's better this way. I'm healthy now..." (Mary).

Laura, Mel and Mary also commented about their experiences with a nutritionist. They reported they looked for a nutritionist not to seek recovery, but to learn how to control their food intake. Laura and Mary said they received a meal plan composed by foods and respective quantities they should eat during the day, but they commented they did not follow it correctly:

"For me it was absurd. But I decided to try only to follow 50\% of it" (Laura).

"I didn't want to follow her meal plan because I thought it would make me fat because I would have to eat so many times during the day! I really resisted following it because food was like an enemy to me, I couldn't see it as something that could help me" (Mary).

\section{Discussion}

Food restriction, irregular meal patterns, fear of certain foods and prohibition of certain foods were dietary behaviors observed in this study that were already identified in patients with anorexia nervosa in other studies. Jenkins \& Odgen 24, Dunker\& Philippi 5, Gonzalez \& Vitousek 25 and Lobera \& Ríos 7 also identified eating behaviors, such as dieting, restricting and controlling food intake. 
Long et al. 26 analyzed mealtimes of inpatients with anorexia nervosa. This group also observed eating rituals including pushing foods around the plate and dissecting food.

The association between feelings of happiness and the control and restriction of the food intake seems to be an important imposition of anorexia nervosa on the interviewees' lives. The association between restricting food and controlling the diet was also identified in the qualitative studies of McNamara et al. 27 and Nordbo et al. 28.

The perception of hunger and the use of strategies to mask it suggest that the term anorexia nervosa is not adequate to describe this eating disorder. Garfinkel 29 observed that individuals with and without anorexia nervosa were able to feel hunger in the same way, and Dunker \& Philippi 5 also observed the use of strategies by individuals with anorexia nervosa to mask their hunger. According to Cordás 30 , the German term pubertaetsmagersucht, which means "pursuit for thinness by teenagers" is more adequate.

Negative feelings associated with eating were created because of a supposed capacity of food to cause weight gain. Negative feelings, such as anxiety, panic, guilt, shame, sadness, anger and embarrassment during mealtimes were also observed in the qualitative study with individuals with anorexia nervosa by Long et al. 26. Macht et al. 31 also observed in their study that normal weight and overweight women felt negative feelings after consuming high caloric foods, because these foods cause weight gain. Nordbo et al. 32 observed that eating was associated with a reduced wish of recovering due to the assumption that this kind of food cause weight gain.

Although the interviewees commented they tried to choose less caloric and healthier foods, it was observed that food preferences significantly affected the interviewees' food choices. Having sweet foods as both food preferences and feared foods was also a characteristic observed in the studies with individuals with anorexia nervosa by Nunes \& Vasconcelos 8 and Dunker \& Philippi 5 . Nunes \& Vasconcelos 8 also observed the attribution of both negative and positive meanings to food. The perception of food as a loved-hated object revealed an existing paradox between desiring and wanting to eat but at the same time hating and not wanting to eat. It explains why an obsessive thinking about food was reported by the interviewees. Giordani 33 also identified this obsessive thinking about food in reports of women with anorexia nervosa.

It is also pertinent to notice that Espeset et al. 34, in their qualitative study with women with anorexia nervosa, considered that negative feelings associated with eating may be not only the consequence but also the cause of anorexic behaviors. For example, sadness and fear were managed through restrictive eating.

Frequent binge-eating episodes followed by compensatory methods characterizes the purgative type of anorexia nervosa, and it will bring not only the clinical consequences of inanition, but also the clinical effects of these compensatory methods 2.

Alvarenga \& Scagliusi 35 also observed that the preferred foods within a binge-eating episode were those prohibited in the daily dietary routine of the individual, and they were usually more caloric foods.

Negative feelings associated with binge-eating episodes, such as loss of control, sadness, shame, anguish, anger, guilty and self-punishment were also observed in the study by McNamara et al. 27 and Nunes \& Vasconcelos 8, and according to Appolinário \& Claudino 36 it is common that binge-eating episodes occur when the individual is hidden, because of these negative feelings.

Eating something unplanned was observed as a trigger for a binge-eating episode. According to Alvarenga \& Scagliusi 35 , the "if you're going to ruin your diet, do it all at once" thinking is caused by a perfectionist perspective in which only restriction is seen as a healthy act. In their review, the authors also observed that emotional factors, such as anxiety, stress, boredom, irritability, guilt, frustration, bad mood and anger could trigger a binge-eating episode.

The treatment of anorexia nervosa is complex, since many conceptions and thoughts in relation to food, eating behavior and body need to be changed in order to eliminate negative feelings and thoughts associated with anorexia nervosa. Jenkins \& Ogden 24 interviewed women recovering from anorexia nervosa, and all of them strongly believed they were not recovered until they ended their obsession with food and weight. However, gaining weight and having anorexia nervosa as a life purpose were factors identified by Nordbo et al. 32 and that could affect the wish of recovering.

The American Dietetic Association recommends having a nutritionist involved with the treatment of individuals with eating disorders ${ }^{1}$. However, patients with anorexia nervosa usually end up 
in a nutritionist office not looking for recovery, but to learn how to control their food consumption. Nunes \& Vasconcelos 8 observed that individuals with eating disorders look for nutritionists to learn how to control their eating behavior. Hence, the nutritionist should be able to detect symptoms and signs of eating disorder in order not to worsen their condition. Souto \& Ferro-Bucher 37 observed that frequent inadequate actions taken by nutritionists, such as prescribing restrictive diets, classifying foods as prohibited and permitted, and not offering individualized diets had negative implications on these women's recovery. According to Rock \& Curran-Celentano 38, it is also important that nutritionists acquire counselling skills and develop a nonjudgmental attitude.

New nutritional strategies have also been developed. Intuitive eating, e.g., is based on trusting the organic stimulus of the body, such as hunger and satiety. Denny et al. 39 observed that individuals who trusted on their physical stimulus to eat presented significantly less chance of developing problems related to eating. The mindful eating technique proposes the use of meditation and making conscious decisions when eating. Proulx 40 has observed the efficacy of this technique on symptoms of bulimia nervosa.

\section{Final considerations}

This qualitative study explored the feelings and perceptions of three women recovering from anorexia nervosa about their eating behavior during and after this eating disorder experience.

Two limitations were observed in this study. Firstly, although it is common to use the methodological procedure of saturation when sampling in qualitative research 41 , this methodology was not used in this study because only three women fit the inclusion criteria during the selection period. Nevertheless, it is important to consider that this study is grounded on a qualitative research, whose importance is not so much attributed to the number of information, but to the comprehension of the personal experience 15,16,17,18,19,20. Secondly, as this study used a retrospective methodology, it is possible the occurrence of recall bias in the interviewee's reports. However, it is pertinent to mention that every experience report is, in essence, a reinterpretation of the experience lived and memory is a good way of accessing a personal experience 15 . Despite these limitations, this study allowed the comprehension and understanding of feelings and perceptions associated with eating behavior of women recovering from anorexia nervosa during and after this eating disorder experience.

Regarding the anorexia nervosa experience, it was possible to observe that anorexia nervosa has imposed distorted thoughts about food and eating. These impositions have brought feelings of anguish, guilt, fear, shame, sadness and anger when eating, together with a love-hate relationship with food and an obsessive thinking about food, which interfered on the eating behavior of the interviewees. Food restriction, skipping meals, strategies to avoid eating, fear and desire related to foods, denying hunger and binge-eating episodes are examples of these interferences. Now in recovery, the interviewees look for a life without deprivation, guilt or rules in relation to their eating behavior, but some feelings of guilty and fear were still detected.

Although similarities were found in the three interviewees' reports, it was observed that each interviewee had its own particular and singular experience. The comprehension of these singularities allowed a better understanding of these experiences. Besides, observing the phenomenon through the perspective of those who lived it, free of pre-established concepts and judgments, creates a more accurate knowledge about the phenomenon of interest.

Comprehending the particular feelings and perceptions of each individual experience may allow health professionals to offer a more effective form of treatment. 


\section{Contributors}

N. Petry, L. C. F. Costa and F. A. G. Vasconcelos participated in the design, analysis and interpretation of the data, writing the article, in the final approval of the version to be published and are co-responsible for all aspects of the work, in guaranteeing the accuracy and integrity of any part of the text.

\section{Acknowledgments}

We would like to thank Ambulatory of Eating Disorders of the Medical Residence in Psychiatry of the Institute of Psychiatry (Ipq) of Santa Catarina State Health Secretariat (SES/SC) for the support.

\section{References}

1. American Psychiatric Association. Diagnostic and statistical manual of mental disorders. 5th Ed. Arlington: American Psychiatric Association; 2013.

2. American Dietetic Association. Position of the American Dietetic Association: nutrition intervention in the treatment of anorexia nervosa, bulimia nervosa, and other eating disorders. J Am Diet Assoc 2006; 102:2073-82.

3. Franko DL, Keshaviah A, Eddy KT, Krishna M, Davis MC, Keel PK, et al. A longitudinal investigation of mortality in anorexia nervosa and bulimia nervosa. Am J Psychiatry 2013; 170:917-25.

4. Rech RR, Halpern R. Prevalence of obesity, overweight and eating disorders in a schoolbased population in Southern Brazil. Journal of Biosafety Health \& Education 2013; 1:111.

5. Dunker KLL, Philippi ST. Hábitos e comportamentos alimentares de adolescentes com sintomas de anorexia nervosa. Rev Nutr 2003; 16:51-60.

6. Fernstrom MH, Weltzin TE, Neuberger S, Srinivasagam N, Kaye WH. Twenty-four-hour food intake in patients with anorexia nervosa and in healthy control subjects. Biol Psychiatry 1994; 36:696-702.

7. Lobera IJ, Ríos PB. Choice of diet in patients with anorexia nervosa. Nutr Hosp 2009; 24:682-7.

8. Nunes AL, Vasconcelos FAG. Transtornos alimentares na visão de meninas adolescentes de Florianópolis: uma abordagem fenomenológica. Ciênc Saúde Coletiva 2010; 15:539-50.
9. Fisher M, Golden NH, Katzman DK, Kreipe RE, Rees J, Schebendach J, et al. Eating disorders in adolescents: a background paper. J Adolesc Health 1995; 16:420-37.

10. Misra M, Tsai P, Anderson EJ, Hubbard JL, Gallagher K, Soyka LA, et al. Nutrient intake in community-dwelling adolescent girls with anorexia nervosa and in healthy adolescents. Am J Clin Nutr 2006; 84:698-706.

11. Dellava JE, Hamer RM, Kanodia A, ReyesRodríguez ML, Bulik CM. Diet and physical activity in women recovered from anorexia nervosa: a pilot study. Int J Eat Disord 2011; 44:376-82.

12. Schebendach JE, Mayer LE, Devlin MJ, Attia E, Contento IR, Wolf RL, et al. Food choice and diet variety in weight-restored patients with anorexia nervosa. J Am Diet Assoc 2011; 111:732-6.

13. Hansson LM, Björck C, Birgegård A, Clinton D. How do eating disorder patients eat after treatment? Dietary habits and eating behaviour three years after entering treatment. Eat Weight Disord 2011; 16:e1-8.

14. Meguerditchian C, Samuelian-Massat C, Valéro R, Begu-Le Corroller A, Fromont I, Mancini J, et al. The impact of weight normalization on quality of recovery in anorexia nervosa. J Am Coll Nutr 2009; 28:397-404.

15. Amatuzzi MM. Psicologia fenomenológica: uma aproximação teórica humanista. Estud Psicol 2009; 26:93-100. 
16. Andrade CC, Holanda AF. Apontamentos sobre pesquisa qualitativa e pesquisa empíricofenomenológica. Estud Psicol 2010; 27:259-68.

17. Silva JMO, Lopes RLM, Diniz NMF. Fenomenologia. Rev Bras Enferm 2008; 61:254-7.

18. Moreira V. O método fenomenológico de Merleau-Ponty como ferramenta crítica na pesquisa em psicopatologia. Psicol Reflex Crit 2004; 17:447-56.

19. Bloc L, Moreira V. Sintoma e fenômeno na psicopatologia fenomenológica de Arthur Tatossian. Rev Latinoam Psicopatol Fundam 2013; 16:28-41.

20. Moreira V. From essence to Lebenswelt as a method in phenomenological psychopathology Estud Psicol 2016; 33:403-11.

21. Bezance J, Holliday J. Adolescents with anorexia nervosa have their say: a review of qualitative studies on treatment and recovery from anorexia nervosa. Eur Eat Disord Rev 2013; 21:352-60.

22. Minayo MCS. Análise qualitativa: teoria, passos e fidedignidade. Ciênc Saúde Coletiva 2012; 17:621-6.

23. World Health Organization. BMI classification. http://apps.who.int/bmi/index. jsp?introPage $=$ intro_3.html (accessed on 16/ Aug/2015).

24. Jenkins J, Ogden J. Becoming 'whole' again: a qualitative study of women's views of recovering from anorexia nervosa. Eur Eat Disord Rev 2012; 20:23-31.

25. Gonzalez VMM, Vitousek KM. Feared food in dieting and non-dieting young women: a preliminary validation of the Food Phobia Survey. Appetite 2004; 43:155-73.

26. Long S, Wallis D, Leung N, Meyer C. "All eyes are on you": anorexia nervosa patient perspectives of in-patient mealtimes. J Health Psychol 2012; 17:419-28.

27. McNamara C, Chur-Hansen A, Hay P. Emotional responses to food in adults with an eating disorder: a qualitative exploration. Eur Eat Disord Rev 2008; 16:115-23.

28. Nordbo RH, Espeset EMS, Gulliksen KS, Skarderud F, Geller J, Holte A. Reluctance to recover in anorexia nervosa. Eur Eat Disord Rev 2012; 20:60-7.

29. Garfinkel PE. Perception of hunger and satiety in anorexia nervosa. Psychol Med 1974; 4 : 309-15.
30. Cordás TA. Transtornos alimentares: classificação e diagnóstico. Rev Psiquiatr Clín 2004; 31:154-7.

31. Macht M, Gerer J, Ellgring H. Emotions in overweight and normal-weight women immediately after eating foods differing in energy. Physiol Behav 2003; 80:367-74.

32. Nordbo RH, Espeset EMS, Gulliksen KS, Skarderud F, Holte A. The meaning of self-starvation: qualitative study of patients' perception of anorexia nervosa. Int J Eat Disord 2006; 39:556-64.

33. Giordani RCF. O corpo sentido e os sentidos do corpo anoréxico. Rev Nutr 2009; 22:809-21.

34. Espeset EMS, Gulliksen KS, Nordbo RH, Skarderud F, Holte A. The link between negative emotions and eating disorder behaviour in patients with anorexia nervosa. Eur Eat Disord Rev 2012; 20:451-60.

35. Alvarenga MS, Scagliusi FB. Tratamento nutricional da bulimia nervosa. Rev Nutr 2010 23:907-18

36. Appolinário JC, Claudino AM. Transtornos alimentares. Rev Psiquiatr Clín 2000; 22:28-31.

37. Souto S, Ferro-Bucher JSN. Práticas indiscriminadas de dietas de emagrecimento e o desenvolvimento de transtornos alimentares. Rev Nutr 2006; 19:693-704.

38. Rock CL, Curran-Celentano J. Nutritional management of eating disorders. Psych Clin North Am 1996; 19:701-13.

39. Denny KN, Loth K, Eisenberg ME, NeumarkSztainer D. Intuitive eating in young adults. Who is doing it, and how is it related to disordered eating behaviours? Appetite 2013; 60:13-9

40. Proulx K. Experiences of women with bulimia nervosa in a mindfulness-based eating disorder treatment group. Eat Disord 2008; 16:52-72.

41. Fontanella BJB, Luchesi BM, Saidel MGB, Ricas J, Turato ER, Melo DG. Amostragem em pesquisas qualitativas: proposta de procedimentos para constatar saturação teórica. Cad Saúde Pública 2011; 27:388-94. 


\section{Resumo}

De acordo com a abordagem fenomenológica, a compreensão plena de um fenômeno pode exigir a observação do mesmo pela ótica daqueles que o vivenciaram. Portanto, para compreender plenamente o comportamento alimentar em relação à anorexia nervosa, o estudo investigou as percepções e sentimentos individuais de três mulheres durante a recuperação da anorexia nervosa. O estudo é caracterizado como uma pesquisa qualitativa com abordagem fenomenológica. Os dados foram coletados através de entrevistas, e analisados de acordo com os passos preconizados por pesquisadores fenomenológicos. Durante a experiência com a anorexia nervosa, foram observados a restrição alimentar e padrões de refeições irregulares. $O$ controle da ingesta alimentar esteve associado à felicidade. Sentimentos de culpa, ansiedade, triste$z a$, medo e raiva estiveram associados à alimentação, onde o alimento era visto como vilão. Também foram observados pensamentos obsessivos em relação aos alimentos e um paradoxo entre gostar de comer e não querer comer. Durante a recuperação, é importante adotar um comportamento alimentar mais flexível, sem sentimentos negativos em relação ao alimento; entretanto, ainda eram detectados sentimentos de culpa e medo. As percepções sobre o contato com nutricionistas revelaram o uso de estratégias ineficazes. Embora os relatos tenham mostrado semelhanças entre si, cada mulher apresentava uma experiência única e particular. Resgatar as memórias e experiências através do discurso foi importante para compreender plenamente as experiências pessoais, e essa compreensão completa pode ajudar os profissionais de saúde a agirem de maneira mais eficiente no tratamento desse fenômeno complexo.

Anorexia Nervosa; Transtornos da Alimentação e da Ingestão de Alimentos; Comportamento

Alimentar; Emoções

\section{Resumen}

De acuerdo con el enfoque fenomenológico, la plena comprensión de un fenómeno puede exigir la observación del mismo desde la óptica de aquellos que lo sufrieron. Por tanto, con el fin de comprender plenamente el comportamiento alimentario, en relación con la anorexia nerviosa, este estudio investigó las percepciones y sentimientos individuales de tres mujeres durante la recuperación de su anorexia nerviosa. El estudio está caracterizado como una investigación cualitativa con enfoque fenomenológico. Los datos fueron recogidos a través de entrevistas y analizados de acuerdo con los pasos preconizados por investigadores fenomenológicos. Durante el proceso de anorexia nerviosa, se observó la restricción alimentaria y los patrones de comidas irregulares. El control de la ingesta alimentaria estuvo asociado a la felicidad. Sentimientos de culpa, ansiedad, tristeza, miedo y rabia estuvieron asociados a la alimentación, donde el alimento era visto como un villano. También se observaron pensamientos obsesivos en relación con los alimentos y una paradoja entre el placer por la comida y no querer comer. Durante la recuperación es importante adoptar un comportamiento alimentario más flexible, sin sentimientos negativos relacionados con los alimentos; sin embargo, todavia se detectaban sentimientos de culpa y miedo. Las percepciones sobre el contacto con nutricionistas revelaron el uso de estrategias ineficaces. A pesar de que los relatos habian mostrado semejanzas entre sí, cada mujer presentaba una experiencia única y particular. Rescatar los recuerdos y experiencias a través del discurso fueron importantes para comprender plenamente las experiencias personales, y esa comprensión completa puede ayudar a los profesionales de salud a actuar de manera más eficiente en el tratamiento de este fenómeno complejo.

Anorexia Nerviosa; Trastornos de Alimentación $y$ de la Ingestión de Alimentos; Conducta Alimentaria; Emociones

Submitted on 23/Mar/2016

Final version resubmitted on 22/Oct/2016

Approved on 28/Nov/2016 